Jap. J. Limnol. 45, 3, 213-219, 1984.

\title{
Growth and Reproduction of Asellus hilgendorfii (Crustacea, Isopoda) Under Laboratory Conditions
}

\author{
Mamoru MrYashita and Masayuki Yasuno
}

\begin{abstract}
The growth and reproduction of Asellus hilgendorfii was studied at $5^{\circ}, 15^{\circ}$ and $25^{\circ} \mathrm{C}$ in the laboratory. The females began to produce their first brood at about $4 \mathrm{~mm}$ in length after five weeks at $25^{\circ} \mathrm{C}$ and after about ten weeks at $15^{\circ} \mathrm{C}$. The animals reared at $5^{\circ} \mathrm{C}$ died before maturation. The mean number of broods per female was 2.6 and 4.3 times at $15^{\circ}$ and $25^{\circ} \mathrm{C}$, respectively. The mean incubation period was 18.3 and 9.4 days, and the mean parturition interval was 29.9 and 15.4 days at respective temperatures. The mean brood size was 27.4 and 34.7 an $15^{\circ}$ and $25^{\circ} \mathrm{C}$, respectively. A. hilgendorfii grew faster and bred more often in their lifetime, compared with other species of the genus Asellus.
\end{abstract}

\section{Introduction}

The freshwater isopod, Asellus hilgendorfii, is an important source of food for fishes (ShIRAISHI et al., 1975), and has a role as the decomposer of the fallen leaves (Sekine and Tsuchiya, 1972). Asellus distributes widely in rivers, lakes, ponds and ditches, and has been known as an indicator of the pollution of organic effluents (HyNEs, 1960). The ecology or life history has been studied for several species of Asellidae: Asellus aquaticus (Andersson, 1969; ØKland, 1978; Adcock, 1979), $A$. intermedius (ELLIS, 1961), A. meridianus (Moon, 1957; Steel, 1961; Chambers, 1977), and A. tomalensis (Ellis, 1971). However, the life history of $A$. hilgendorfii, which is the only surface-water Asellidae known from Japan (Matsumoto, 1973), is virtually unknown. The objective of the present study was to investigate the growth and reproduction of $A$. hilgendorfi under laboratory conditions.

\section{Materials and methods}

$A$. hilgendorfii used in the present study was collected from the River Tama, in July 1978, and has been bred in the laboratory.

The experiments were carried out at $5^{\circ}$, $15^{\circ}$ and $25^{\circ} \mathrm{C}$, with alternating light and dark periods of $12 \mathrm{hr}$. The light intensity was about 3,000 lux. The animals were fed on fallen chestnut leaves. The leaves were soaked in groundwater for one week prior to use. Rearing water and the food were changed weekly.

For the growth study, eight juvenile Asellus just departed from the pouch were placed in individual plastic containers, $15 \mathrm{~cm}$ in diameter and $9 \mathrm{~cm}$ in height, containing $800 \mathrm{~m} l$ of groundwater. Twenty replicates were provided for each temperature, of which one or two containers was sacrificed for measuring the body length and body weight at weekly intervals. Body length was measured under a binocular microscope from the base of the antennules to the end of the abdomen.

To determine brood size, incubation period and parturition interval, a pair of Asellus were kept in individual $200 \mathrm{~m} l$ glass beakers containing $100 \mathrm{~m} l$ of groundwater. Twenty replicates were provided for each temperature. All beakers were examined every day for deposition of eggs into the pouch and release of young therefrom.

\section{Results}

The growth of $A$. hilgendorfii reared at $5^{\circ}, 15^{\circ}$ and $25^{\circ} \mathrm{C}$ are shown in Fig. 1. When young left the pouch, the body length was $1.03 \mathrm{~mm}$, and the mean body weight was $0.024 \mathrm{mg}$. The sex of animals could be distinguished at $2.5 \mathrm{~mm}$ in body length when reared at $15^{\circ} \mathrm{C}$, and at $3.5 \mathrm{~mm}$ 
when reared at $25^{\circ} \mathrm{C}$. Only eight percent of 88 animals reared at $5^{\circ} \mathrm{C}$ survived after five months, when they had attained about $1.5 \mathrm{~mm}$ in length and $0.2 \mathrm{mg}$ in weight. The growth of the animals was significantly different among $5^{\circ}, 15^{\circ}$ and $25^{\circ} \mathrm{C}$ as indicated in Fig. 1. There was a significant difference in the growth rate between males and females after sex differentiation.

The relationship between body length and body weight may be expressed as $\log Y=3.148 \log X-1.598$ for females, $\log Y=2.750 \log X-1.373$ for males and $\log Y=2.945 \log X-1.506$ for young, where $Y$ is wet body weight in $\mathrm{mg}$ and $X$ is body length in mm (Fig. 2). Females are somewhat heavier than males of comparable lengths. Water temperature for rearing did not affect the regression. The data at both $15^{\circ}$ and $25^{\circ} \mathrm{C}$ were plotted together in Fig. 2.

The number of young per brood at $15^{\circ}$ and $25^{\circ} \mathrm{C}$ is shown in Fig. 3. Brood size,

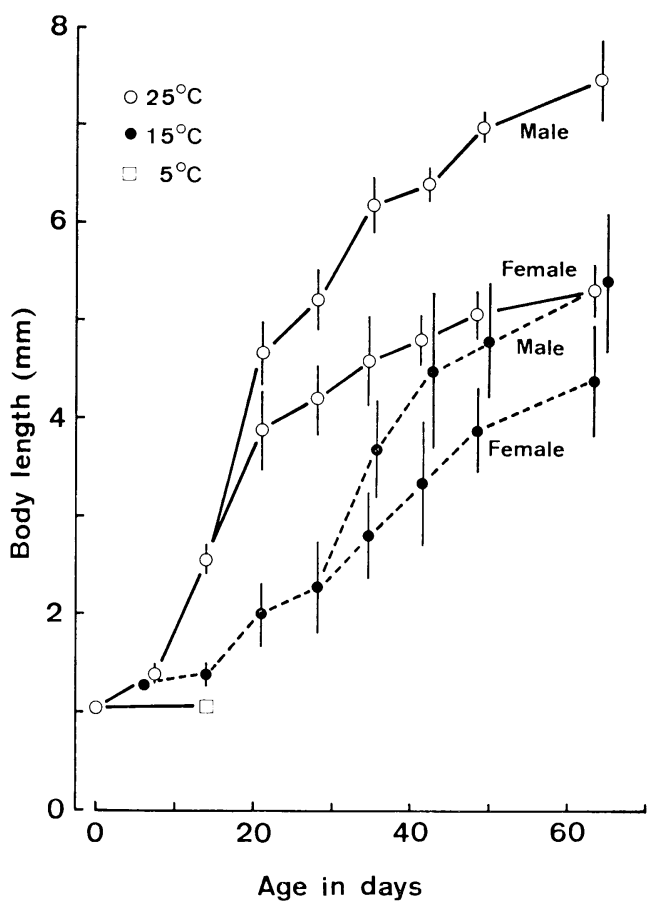

Fig. 1. Growth of Asellus hilgendorfii reared at $5^{\circ}, 15^{\circ}$ and $25^{\circ} \mathrm{C}$ in the laboratory. Vertical bar indicates $95 \%$ confidence limit of the mean.

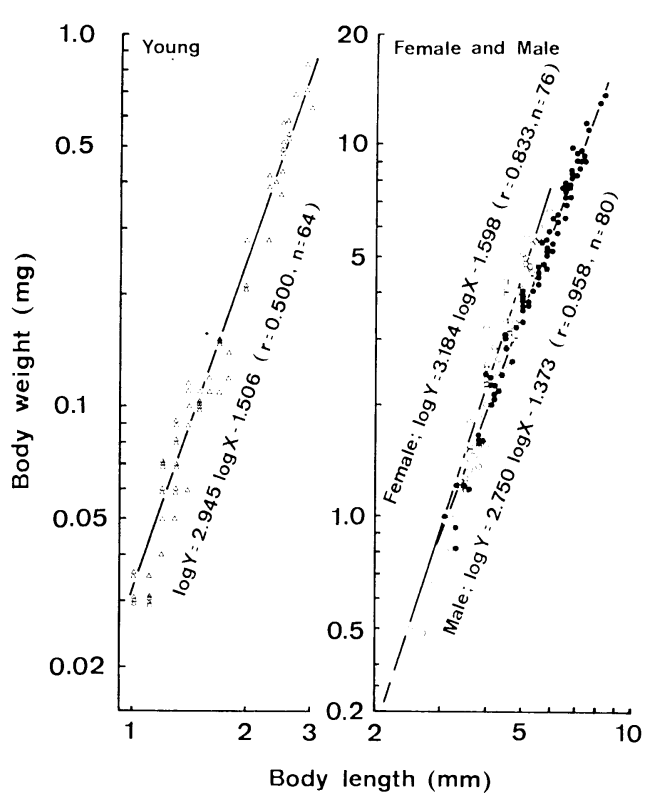

Fig. 2. Relationship between body length and body weight for Asellus hilgnedorfii. $\bigcirc$ : Female,

Male

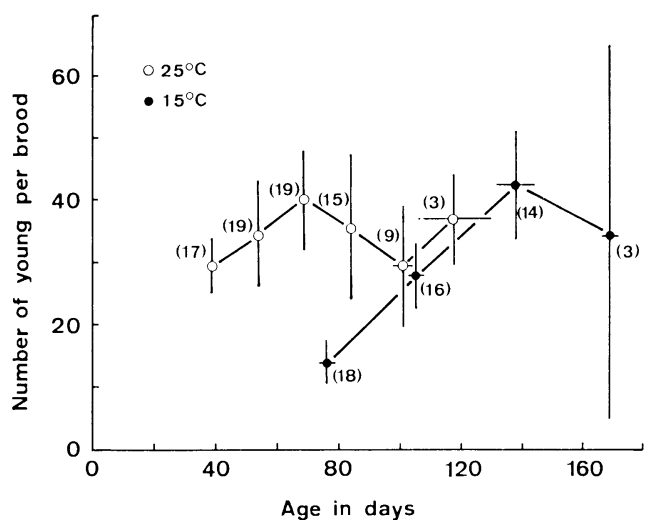

Fig. 3. Number of young per brood for Asellus hilgendorfi reared at $15^{\circ}$ and $25^{\circ} \mathrm{C}$ in the laboratory. Vertical and holizontal bars indicate 95\% confidence limits of the mean. Numbers in parentheses are animal numbers used.

incubation period and parturition interval at the respective temperatures are shown in Table 1. The females began to produce the first brood at about $4 \mathrm{~mm}$ in length after five weeks at $25^{\circ} \mathrm{C}$ and after about ten weeks at $15^{\circ} \mathrm{C}$. The animals reared at 
Table 1. Selected life history charactristics of Asellus hilgendorfii reared at $15^{\circ}$ and $25^{\circ} \mathrm{C}$ in the laboratory.

\begin{tabular}{|c|c|c|c|c|c|}
\hline \multirow[b]{2}{*}{ Temperature } & \multicolumn{2}{|l|}{$15^{\circ} \mathrm{C}$} & \multicolumn{2}{|c|}{$25^{\circ} \mathrm{C}$} & \multirow{2}{*}{$t$} \\
\hline & Mean \pm S. D. & Range & Mean \pm S. D. & Range & \\
\hline Life span (days) & $>260 \quad(20)$ & $148-(365)^{a}$ & $100.6 \pm 26.2(20)$ & $27-135$ & - \\
\hline Number of broods & $2.6 \pm 0.8(20)$ & $1-\quad 4$ & $4.3 \pm 1.2(19)$ & $2-6$ & $5.682^{* *}$ \\
\hline Brood size & $27.4 \pm 16.6$ & $3-79$ & $34.7 \pm 16.6$ & $1-83$ & $2.483^{*}$ \\
\hline $\begin{array}{l}\text { Total number of young } \\
\text { produced per female }\end{array}$ & $69.8 \pm 35.4(20)$ & $6-156$ & $156.6 \pm 45.0$ & $80-231$ & 6. $721^{* *}$ \\
\hline $\begin{array}{l}\text { Age at first (days) } \\
\text { production }\end{array}$ & $76.1 \pm 6.4(18)$ & $60-92$ & $38.5 \pm 2.7(17)$ & $35-43$ & $66.567^{* *}$ \\
\hline Incubation period (days) & $18.3 \pm 3.2(23)$ & $11-\quad 24$ & $9.4 \pm 1.4(69)$ & $7-14$ & $18.764^{* *}$ \\
\hline $\begin{array}{l}\text { Parturition (days) } \\
\text { interval }\end{array}$ & $29.9 \pm 2.5(26)$ & $27-\quad 33$ & $15.4 \pm 1.7(63)$ & $13-19$ & $32.373^{* *}$ \\
\hline
\end{tabular}

Values in parentheses are animal numbers used.

a) Observation was lasted one year, when six of the twenty females survived.

$* p<0.05 * * p<0.001$

$5^{\circ} \mathrm{C}$ died before maturation.

The mean number of broods per female was 2.6 and 4.3 times, and the maximum number was 4 and 6 times at $15^{\circ}$ and $25^{\circ} \mathrm{C}$, respectively. There was a significant difference $(t=5.682, p<0.001)$ in the number of broods between $15^{\circ}$ and $25^{\circ} \mathrm{C}$. The number of young per brood increased gradually until the third brood but decreased after that at both $15^{\circ}$ and $25^{\circ} \mathrm{C}$. The brood size differed significantly among the first three broods at $15^{\circ} \mathrm{C}$ (between 1st and 2nd brood, $t=4.444, \quad p<0.001$; between 2nd and 3rd, $t=2.772, \quad p<0.01$; between 1 st and 3rd, $t=6.215, p<0.001$ ), but did not differ at $25^{\circ} \mathrm{C}$. The mean brood size was 27.4 and 34.7 at $15^{\circ}$ and $25^{\circ} \mathrm{C}$, respectively, which were significantly different $(t=2.483, p<0.05)$. The size of the first brood at $15^{\circ} \mathrm{C}$ was significantly smaller than at $25^{\circ} \mathrm{C}(t=5.582, p<0.001)$. The mean total number of young produced per female in lifetime was significantly different at 69.8 and $156.6(t=6.721, p<0.001)$; the maximum number was 156 and 231 at $15^{\circ}$ and $25^{\circ} \mathrm{C}$, respectively. The mean incubation period from deposition of eggs in the pouch to departure of fully developed young was 18.3 and 9.4 days, and the mean parturition interval was 29.9 and 15.4 days at $15^{\circ}$ and $25^{\circ} \mathrm{C}$, respectively. These differences according to temperature were statistically significant (incubation period, $t=18.764, \quad p<0.001$; parturition interval, $t=32.373, p<0.001$ ).

Survival curves of females reared at $15^{\circ}$ and $25^{\circ} \mathrm{C}$ are shown in Fig. 4. The mean longevity for females reared at $25^{\circ} \mathrm{C}$ was 101 days, against 260 days or more at $15^{\circ} \mathrm{C}$.

The number of eggs or young per brood increased in proportion to the size of the female. Linear relationships were obtained between the number of egg in the pouch and the female body length, as well as between the number of young released from the pouch and the body length of female; i.e., $Y=18.928 X-46.730$ for the number of eggs and $Y=20.349 X-71.174$

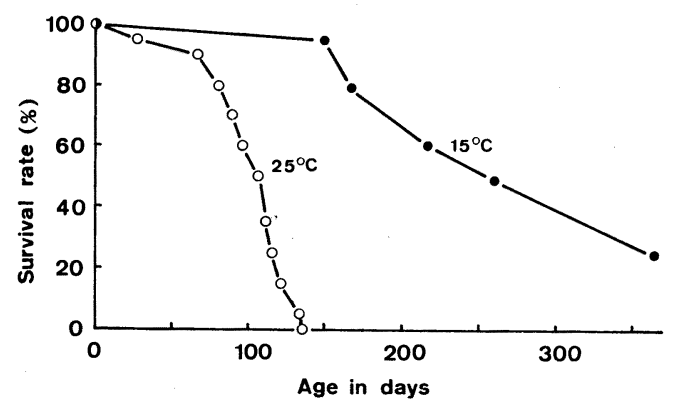

Fig. 4. Survivorship curves for females of Asellus hilgendorfi reared at $15^{\circ}$ and $25^{\circ} \mathrm{C}$. 


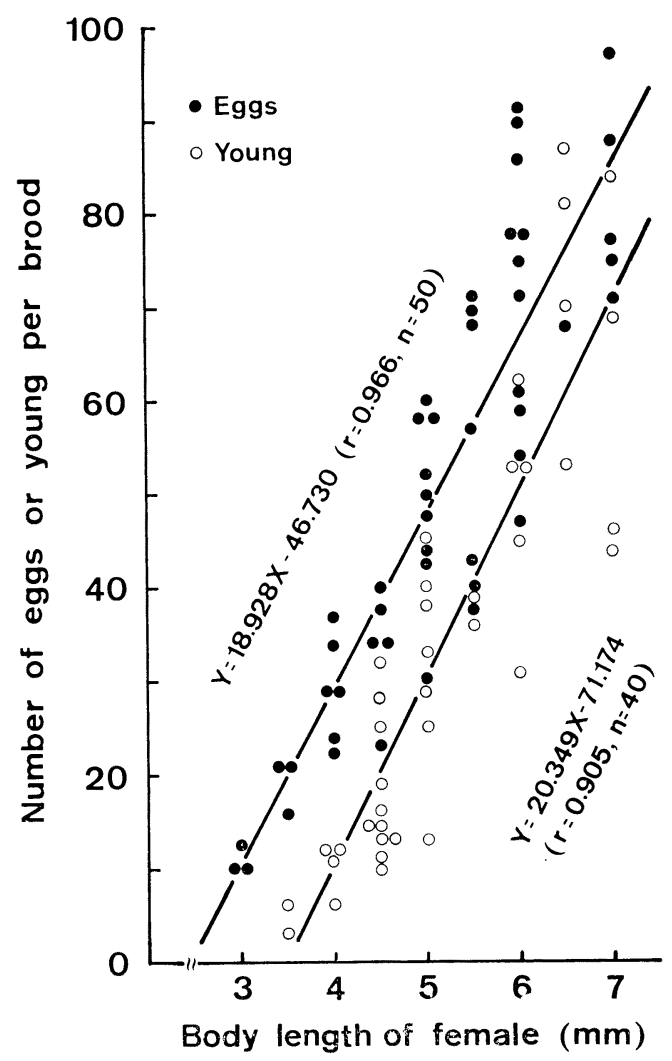

Fig. 5. Relationship between number of eggs or young per brood and body length of females for Asellus hilgendorfii.

for the number of young, where $Y$ is fecundity and $X$ is body length of females in $\mathrm{mm}$ (Fig. 5). The smallest female bearing eggs measured $3.0 \mathrm{~mm}$, and the smallest to release young was $3.5 \mathrm{~mm}$. When the females were divided into body length groups of $3.5-4.0 \mathrm{~mm}, 4.5-5.0 \mathrm{~mm}$, $5.5-6.0 \mathrm{~mm}$ and $6.5-7.0 \mathrm{~mm}$, the rates of reduction in number from eggs in the pouch to young released were $68.0,46.9$, 19.4 and $15.8 \%$, respectively.

\section{Discussion}

The principal food of Asellus is decaying vegetable matter with its associated flora of fungi, bacteria and other microorganisms (MARCUS et al., 1978). In the laboratory, elm leaves (Ellis, 1961; HyNES and Williams, 1965; Brown, 1976;
FrASER et al., 1978), alder leaves (Ellis, 1971; Prus, 1971), poplar leaves (Ellis, 1961; ZimaKowsKA-GNoINSKA, 1977; OsEID, 1978) and oak leaves (WilloughBy and Marcus, 1979) have been used as a food for Asellus. In the present study, $A$. hilgendorfii grew well on chestnut leaves.

ELlIS (1961) reported the growth of $A$. intermedius at four different temperatures in the laboratory. In his study, about 1.2 $\mathrm{mm}$ young in the average length at the beginning became $1.4 \mathrm{~mm}, 1.5 \mathrm{~mm}, 1.8$ $\mathrm{mm}$ and $3.6 \mathrm{~mm}$ at $7.7^{\circ}, 12.8^{\circ}, 18.3^{\circ}$ and $23.9^{\circ} \mathrm{C}$, respectively, after 30 days. In the present study, the mean length of A. hilgendorfii at 28 days was $2.18 \mathrm{~mm}$ and $4.69 \mathrm{~mm}$ at $15^{\circ}$ and $25^{\circ} \mathrm{C}$, respectively, suggesting that the growth of $A$. hilgendorfii is more rapid than that of $A$. intermedius. The growth of $A$. hilgendorfii used in the present study was expressed in relation to degree-days above $3^{\circ} \mathrm{C}$, as also reported for $A$. aquaticus (ANDERSSON, 1969; ØKLAND, 1978). A. hilgendorfii did not grow at $5^{\circ} \mathrm{C}$, which is in agreement with the minimum temperature for growth described above. There was no size difference between male and female $A$. aquaticus and $A$. meridianus (SteEL, 1961) until the animals became $3 \mathrm{~mm}$ in length, but thereafter males grew more rapidly. The size differentiation in $A$. hilgendorfii due to sex began at $2.5 \mathrm{~mm}$ with $15^{\circ} \mathrm{C}$ and at $3.5 \mathrm{~mm}$ for $25^{\circ} \mathrm{C}$. $A$. aquaticus (STEEL, 1961; CHAMBERS, 1977; ØKland, 1978), A. meridianus (Steel, 1961; Chambers, 1977) and $A$. intermedius (Ellis, 1961) breed twice in their life, A. tomalensis (Ellis, 1971) breeds only once, whereas, A. hilgendorfii bred a maximum of six times during their lifetime (approximately 4 month).

ANDERSSON (1969) reported that the incubation period of $A$. aquaticus was dependent on temperature and directly proportional to the number of degree-days above $4^{\circ} \mathrm{C}$. ØKLAND (1978) also reported the estimated incubation period of $A$. aquaticus to be 23-35 days, corresponding to about 300 degree-days above $4^{\circ} \mathrm{C}$. The 
Table 2. Regression of fecundity on size of Asellus species.

\begin{tabular}{lcccc}
\multicolumn{1}{c}{ Species } & Stage of brood & Regression* & Size of female (mm) & Auther \\
A. aquaticus & eggs & $Y=19.80 X-65.81$ & $4-10$ & Steel $(1961)$ \\
A. meridianus & eggs & $Y=16.04 X-41.44$ & $3-7$ & Steel (1961) \\
A. tomalensis & eggs & $Y=9.08 X-33.60$ & $5-8$ & Ellis (1971) \\
A. tomalensis & embryos & $Y=3.91 X-1.75$ & $6-9$ & Ellis (1971) \\
A. intermedius & eggs and embryos & $Y=26.78 X-119.21$ & $4-12$ & Ellis (1961) \\
A. hilgendorfii & eggs & $Y=20.35 X-71.17$ & $3-7$ & Present study \\
A. hilgendorfii & young & $Y=18.93 X-46.73$ & $3.5-7$ & Present study
\end{tabular}

* In the regression equation, $Y=$ fecundity and $X=$ body length of female.

incubation period of $A$. intermedius was expressed in relation to degree-days above $1^{\circ} \mathrm{C}$, and about 288 degree-days were required for the development of the eggs (Ellis, 1961). The temperature sum of $A$. hilgendorfii used in the present study was about 194 degree-days above $4^{\circ} \mathrm{C}$, suggesting that their embryos grow more rapidly than those of $A$. aquaticus and A. intermedius. However, the size of females required to produce young did not differ between $A$. hilgendorfii and other species. Females of $A$. aquaticus matured at about $3.5 \mathrm{~mm}$ and those of $A$. meridianus at about $3 \mathrm{~mm}$ in length (STEEL, 1961), A. hilgendorfii females also matured at $3 \mathrm{~mm}$.

The number of eggs in the pouch increased in proportion to the size of the female $A$. hilgendorfii. Similar relationships have been noted for other species also (Table 2). The fecundity of $A$. hilgendorfii is almost the same as that of $A$. aquaticus. The range of the size of $\mathrm{fe}$ males to produce young was different among species.

When the number of eggs was compared with the number of embryos in $A$. aquaticus, A. meridianus and $A$. intermedius of comparable female length, a reduction in the numbers from egg to embryo stage was observed (Ellis, 1961, 1971; SteEL, 1961; Andersson, 1969). In the case of $A$. hilgendorfii, the similar reduction in the brood size was observed when comparably sized females were examined.
Steel (1961) reported that eggs and embryos were expelled from the pouch during development in $A$. aquaticus and A. meridianus. ANDERsson (1969) attributed the loss of brood to the increasing volume of the embryos during development in relation to the constant volume of the pouch. In the present study, the mortality rate of the brood decreased with the increase of female body length in $A$. hilgendorfii (Fig. 5). Since the number of young released from the pouch can be expressed in proportion to the cube of body length in $A$. hilgendorfii, the size of brood seems to be regulated by a capacity of the pouch.

Females of $A$. hilgendorfii reared at $25^{\circ} \mathrm{C}$ matured earlier and had higher fecundity, but shorter life span than those reared at $15^{\circ} \mathrm{C}$. The range of water temperature at the collection site in the River Tama was from $7.5^{\circ} \mathrm{C}$ in February to $30^{\circ} \mathrm{C}$ in August, and pregnant females were found from March (water temperature, $\left.8.3^{\circ}-10.2^{\circ} \mathrm{C}\right)$ to December $\left(11.2^{\circ}-11.9^{\circ} \mathrm{C}\right)$. The overwintering females start the breeding in March, and the new generation is able to mature in May. The alternation of generations would be 4 or 5 times in a year.

A. hilgendorfii distributed widely in Japan and has been found to survive an alpine lake such as Lake Yunoko in which the ice cover period lasted for about four months in winter. Studies on the population dynamics of this species must be undertaken. 


\section{Acknowledgements}

We wish to express our thanks to Mr. M. Sando, Mrs. K. Furuya, Mrs. K. Sando and Miss C. HARIKAE for their assistance in carrying out the present study. Thanks are also due to Mr. T. KiкUсні and Mrs. M. KІкUсні for collection of the material used in the present study.

\section{摘 要}

ミズムシ (Asellus hilgendorfii) の成長, 産仔数, 産仔周期と水温との関係を実験室で調べた。飼育は $5^{\circ}, 15^{\circ}, 25^{\circ} \mathrm{C}$ の土環境室において行ない，邻と して栗の枯葉を与えた. $25^{\circ} \mathrm{C}$ における成長は雌雄共 に $15^{\circ} \mathrm{C}$ の成長を上まわっていた， $5^{\circ} \mathrm{C}$ での成垃は ほとんど見られなかった。雌は体长が約 $4 \mathrm{~mm}$ にな ると産仔する. $25^{\circ} \mathrm{C}$ では約 5 週目， $15^{\circ} \mathrm{C}$ では約 11 週目に初産がみられる. $25^{\circ} \mathrm{C}$ では平均 4.3 回, $15^{\circ} \mathrm{C}$ では平均 2.6 回産仔する。 $25^{\circ} \mathrm{C}$ における産仔周期お よび抱卵期間は約 15 日と約 9 日で， $15^{\circ} \mathrm{C}$ のほぼ半 分の期間であった。 产仔数は $15^{\circ}, 25^{\circ} \mathrm{C}$ とも 3 回 目の産仔まで増加し，その後減少した。 1 回当りの平 均産仔数は $25^{\circ} \mathrm{C}$ では 34.7 個体, $15^{\circ} \mathrm{C}$ では 27.4 個 体で，最高は $25^{\circ} \mathrm{C}$ で 83 個体， $15^{\circ} \mathrm{C}$ では 56 個体 であった．また一生涯における平均産仔数は $25^{\circ} \mathrm{C}$ で 156.6 個体, $15^{\circ} \mathrm{C}$ で69.8 個体であった。

\section{References}

Adсоск, J. A. (1979) : Energeticus of a population of the isopod Asellus aquaticus; Life history and production. Freshwater Biol., 9: 343-355.

Andersson, E. (1969) : Life cycle and growth of Asellus aquaticus (L.) with special reference to the effects of temperature. Rep. Inst. Freshwater Res. Drottningholm, 49: 5-26.

Brown, B.E. (1976) : Observation on the tolerance of the isopod Asellus meridianus Rac. to copper and lead. Water Res., 10: 555-559.

Chambers, M. R. (1977): A comparison of the population ecology of Asellus aquaticus (L.) and Asellus meridianus Rac. in the reed beds of the Tjeukemeer. Hydrobiologia, 53: 147154.

ElLIS, R. J. (1961) : A life history study of Asellus intermedius Forbes. Trans. Amer. Micros. Soc., 80: 80-102.

ElLis, R. J. (1971) : Notes on the biology of the isopod Asellus tomalensis Harford in an intermittent pond. Trans. Amer. Micros. Soc., 90: 51-61.

Fraser, J., D. T. Parkin and E. Verspoor (1978) : Tolerance to lead in the freshwater isopod Asellus aquaticus. Water Res., 12: 637-641.

Hynes, H. B. N. (1960) : The biology of polluted waters. Liverpool Univ. Press.

Hynes, H. B. N. and W. D. Williams (1965): Experiments on competition between two Asellus species (Isopoda Crustacea). Hydrobiologia, 26: 203-210.

Marcus, J. H., D. W. Sutcliffe and L.G. Willoughis (1978): Feeding and growth of Asellus aquaticus (Isopoda) on food items from the littoral of Windermere, including green leaves of Elodes canadensis. Freshwater Biol., 8: 505-519.

Matsumoto, K. (1973) : Isopoda, p. 473-488. In: Ueno, M. (ed.), Freshwater biology of Japan. Hokuryukan Pub. Co.

Moon, H.P. (1957) : The distribution of Asellus in Windermeer. J. Anim. Ecol., 26: 113-123.

ØKLAND, K. A. (1978) : Life history and growth of Asellus aquaticus (L.) in relation to environment in eutrophic lake in Norway. Hydrobiologia, 59: 243-259.

Oseid, D. M. (1978) : A comparison of the variability of Asellus communis (Crustacea: Isopoda) and Gammarus seudolimnaeus (Crustacea: Amphipoda) and suitability for joint bioassays. Bull. Environ. Contam. Toxicol., 20: 461-469.

Prus, T. (1971) : The assimilation efficiency of Asellus aquaticus L. (Crustacea, Isopoda). Freshwater Biol., 1: 287-305.

Serine, K. and A. Tsuchiya (1972) : Feeding activity of Asellus hilgendorfii with special reference to its distribution in Lake Yunoko, Nikko. Annu. Rep. Yunoko Res. Group 1971: 45-55.

Shiraishi, Y., K. Matsumoto, A. Tsuchiya, K. Serine and H. Кікuснi (1975): Productivity of the community in Lake Yunoko, 2.5.4. Benthos. p. 80-86. In: Mori, S. and G. Үамамото (eds.), Productivity of communities in Japanese inland waters-JIBP Synthesis, 10. Univ. Tokyo Press.

Steer, E. A. (1961) : Some observation on the life history of Asellus aquaticus (L.) and Asellus meridianus Racovitza (Crustacea: Isopoda). Proc. Zool. Soc. Lond., 137: 7187.

Willoughby, L. G. and J. H. Marcus (1979): Feeding and growth of isopod Asellus aquaticus on actinomycetes, considers as model filamentous bacteria. Freshwater Biol., 9: 441-449. 
Zimakowska-Gnoinska, D. (1977) : Toxicological and physiological aspects of the action of herbicide, sodium salt of 2,4-D, on Asellus aquaticus L. (Isopoda). Pol. Arch. Hydrobiol., 24: 389-411.
（著者：宮下衛・安野正之, 干305 荻城県筑波郡谷 田部町小野川16-2; Mamoru Miyashita and Masayuki Yasuno, Division of Environmental Biology, National Institute for Environmental Studies, Yatabe, Tsukuba 305)

Accepted: 21 May 1984 